\title{
INHIBITORY ACTIVITY OF THE ACTIVE COMPOUND OF ETHYL ACETATE FRACTION OF TAMOENJU (Hibiscus surattensis L.) LEAVES AGAINST $\alpha$-GLUCOSIDASE AND DIPEPTIDYL PEPTIDASE-4 ENZYMES
}

\author{
Yuliet $^{1,2 *}$, EY Sukandar ${ }^{1}$, Krisyanti Budipramana ${ }^{3}$, IK Adnyana ${ }^{1}$ \\ ${ }^{1}$ Department of Pharmacology and Clinical Pharmacy, School of Pharmacy, Bandung Institute of \\ Technology, Bandung-40132, Indonesia \\ ${ }^{2}$ Department of Pharmacy, Faculty of Mathematics and Natural Sciences, Tadulako University, \\ Palu-94118, Central Sulawesi, Indonesia \\ ${ }^{3}$ Department of Pharmaceutical Biology, Faculty of Pharmacy, University of Surabaya, \\ Surabaya-60293, Indonesia \\ *E-mail: yuliet_susanto@yahoo.com
}

\begin{abstract}
The ethyl acetate fraction (EAF) of tamoenju (Hibiscus surattensis L.) leaves, used as a traditional antidiabetic agent in Central Sulawesi, has high inhibitory activity against $\alpha$-glucosidase and dipeptidyl peptidase-4 (DPP-4). The aim of this study was to isolate the active compound of EAF that was carried out by step gradient polarity extraction, then separated and purified by chromatography. The structure was identified and characterized using NMR spectroscopy and LC-MS. $\alpha$-glucosidase inhibitory activity was evaluated using the in vitro standard $\alpha$-glucosidase inhibition test, while DPP-4 activity was evaluated by ex vivo DPP-4 inhibitor test using rat blood serum as the enzyme source. $\mathrm{IC}_{50}$ values were determined by nonlinear regression curve and fit using GraphPad Prism 8 and were expressed as mean \pm SEM. In this research, we obtained the isolated compound was identified as kaempferol, which was isolated for the first time from this plant. The isolate exhibited potent $\alpha$-glucosidase and DPP-4 inhibition with $\mathrm{IC}_{50}$ values of $27.78 \pm 0.86$ and $7.37 \pm 0.06 \mu \mathrm{g} / \mathrm{mL}$, respectively. Acarbose and sitagliptin as positive control had $\mathrm{IC}_{50}$ values of $17.80 \pm 0.27$ and $25.56 \pm 0.43 \mu \mathrm{g} / \mathrm{mL}$, respectively. The isolate level by LC-MS was estimated to be $182.23 \mathrm{mg} / \mathrm{g}$ isolate. Therefore, tamoenju leaves have great potential as functional foods and in the development of antidiabetic drugs.
\end{abstract}

Keywords: $\alpha$-Glucosidase, Antidiabetic, Dipeptidyl peptidase-4, Kaempferol, Tamoenju, Hibiscus surattensis L.

(C) RASĀYAN. All rights reserved

\section{INTRODUCTION}

There is high plant diversity in Indonesia, but there are still many plants that have not been utilized. Although modern medicine has developed rapidly, Indonesians have always used plants for medicinal purposes. Indonesia has a huge ethnic and cultural diversity. Many endemic plants found in certain areas are used for the treatment of various diseases by tribes in Indonesia ${ }^{1,2}$. Tamoenju (Hibiscus surattensis L.) is a plant found in the village of Alindau, Donggala Regency, Central Sulawesi, Indonesia (Fig.-1).

In general, these plants, especially the leaves, are used vegetable salad ${ }^{3,4}$ and traditional medicines for diabetes $^{5}$ and hepatitis ${ }^{6,7}$. Some countries, such as Nigeria, India, West Africa, and Tanzania, use this plant to treat hypertension ${ }^{8}$, urethritis and venereal diseases ${ }^{3}$, malaria, wounds, abscesses, gonorrhea, stomach pain, and cough ${ }^{9}$.

Previous pharmacological studies demonstrated that crude leaf extracts possess anti-inflammatory, antioxidant, analgesic, and antidiarrheal activities ${ }^{10}$. The essential oil of $H$. surattensis $\mathrm{L}$. calyces is used as a natural antibacterial ${ }^{4}$. In our previous research, ethyl acetate fraction (EAF) from ethanol extract (EE) of tamoenju plant leaves was found to exert antidiabetic effect by improving impaired glucose tolerance. Furthermore, EAF exhibited better inhibition of $\alpha$-glucosidase compared to the crude extract, $n$-hexane

Rasayan J. Chem., 13(1), 826-835(2020)

http://dx.doi.org/10.31788/RJC.2020.1325607

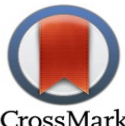


RASĀYAN J. Chem.

Vol. 13 | No. 2 |826 - 835| April - June | 2020

fraction (NHF), and water fraction (WF $)^{11}$. The phytochemical constituent analysis of EAF showed high levels of phenolic and flavonoid compounds. EAF showed potent antioxidant activity and inhibitory activity against dipeptidyl peptidase-4 (DPP-4) enzyme. These effects have a positive correlation with the total flavonoid content of $\mathrm{EAF}^{9}$. Flavonoid compounds can influence the biological targets involved in type 2 diabetes mellitus, such as $\alpha$-glucosidase and DPP- $4{ }^{12}$.

Thus, EAF was a potential fraction to be developed as an antidiabetic agent. Therefore, EAF from EE was selected to isolate the active compounds for further research. Isolation and elucidation of the structure of active compounds contained in extracts or fractions can be used for the development of antidiabetic drugs. Based on this, we report the isolation and identification of isolated compounds from EAF. Enzymes such as $\alpha$-glucosidase and DPP-4, which are related to insulin secretion, have been reported as new targets for type 2 diabetes mellitus therapy. Therefore, this study was conducted to investigate the $\alpha$-glucosidase and DPP-4 inhibitory activities of isolate fraction compounds as two of the essential hypoglycemic mechanisms. It is studied for the first time on extracts of tamoenju plant leaves.

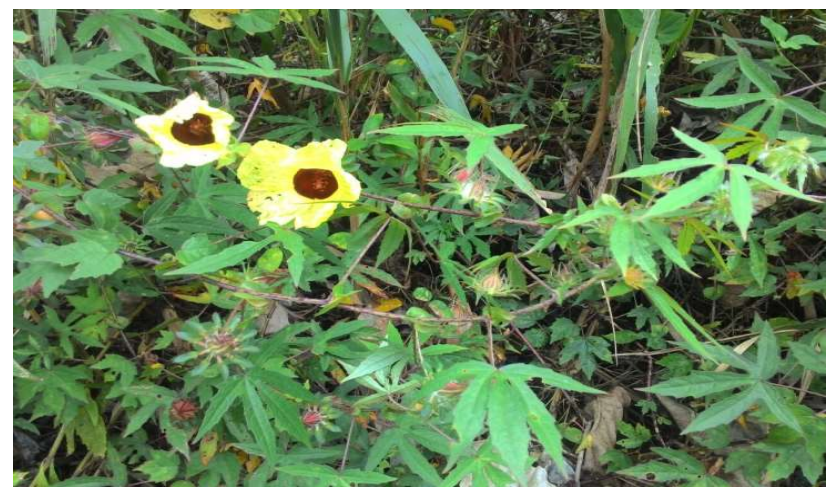

Fig.-1: Tamoenju Plant (Hibiscus surattensis L.)

\section{EXPERIMENTAL}

\section{Materials and Equipment}

Solvents were technical grade ethanol, ethyl acetate, and n-hexane, which were purchased from Brataco Chemicals (Bandung, Indonesia). Other chemicals and reagents for analysis were analytical grades. The $\alpha$-glucosidase enzyme from Saccharomyces cerevisiae G5003-100UN (CAS 9001-42-7), p-nitrophenyl $\alpha$ D-glucopyranoside (pNPG) (CAS 3767-28-0) and bovine serum albumin was from Sigma Aldrich, USA. Acarbose (Glucobay ${ }^{\mathbb{B}}$ ), Kaempferol standard (Andalas Sitawa Fitolab, Padang, Indonesia), and DPP-4 Spectrofluorometry Activity Assay Kit were from Sigma Aldrich, USA (Lot. 2L02K07790). The leaves of $H$. surattensis L. were collected from Alindau, Sindue Tobata, Central Sulawesi, Indonesia, from August to September 2016. The leaves were identified in Herbarium Bandungense, School of Life Sciences and Technology, Bandung Institute of Technology, Indonesia, under the number 1791/II.CO2.2/PL/2017. The instrument used was the nuclear magnetic resonance (NMR) Agilent DD2 spectrometer, which operates at $500 \mathrm{MHz}\left({ }^{1} \mathrm{H}\right)$ and $125 \mathrm{MHz}\left({ }^{13} \mathrm{C}\right)$ with deuterated acetone $\left(\left(\mathrm{CD}_{3}\right)_{2} \mathrm{CO}\right)$ as the solvent. Chromatography column was carried out using Silica gel 60 (Merck) and thin-layer chromatography (TLC) plates (Merck Kieselgel 60 F254). Spots on the TLC plates were detected by reagent spray $10 \% \mathrm{H}_{2} \mathrm{SO}_{4}$ in ethanol followed with heating at $110^{\circ} \mathrm{C}$ and sitroborat. Mass Spectra (MS) were measured with Waters UPLC-ESI-TOFMS system (Acquity UPLC Xevo QTof) (Waters Corporation, Milford). Microwell plate (IWAKI Pyrex), microwell for fluorescence (Thermo Scientific ${ }^{\mathrm{TM}}$ ), and microplate reader (Tecan Infinite M200 PRO).

\section{General Procedure}

The leaves were ground and macerated using $96 \%$ ethanol solvent for five days. The crude EE mixed with warm distilled water (1:1) to remove chlorophyll, filtered, and then partitioned by liquid-liquid partition using solvents having high polarity (n-hexane and ethyl acetate) to obtain the NHF, EAF, and WF. The EAF $(20.0 \mathrm{~g})$ was fractionated and isolated by gravity column chromatography on silica gel 60 to produce eight fractions (EAF1-8). EAF2 (997.00 mg) was subjected to column chromatography over silica gel 
RASĀYAN J. Chem.

Vol. 13 | No. 2 |826 - 835| April - June | 2020

using the same eluent to produce nine subfractions (SEAF1-9). SEAF2-5 (230.00 mg) were separated on a column of silica gel to produce subfraction SSEAF1-25. SSEAF3-9 (136.50 mg) underwent rechromatography using the same method to yield IEAF1-64. IEAF34-39 were combined and dried to get pure compounds $(17.2 \mathrm{mg})$. Chromatography was carried out by stepwise gradient elution using solvents of gradually increasing polarity ${ }^{13}$. The mobile phase started from n-hexane:ethyl acetate 100:0, 90:10, $80: 20,70: 30,60: 40,50: 50,40: 60,30: 70,20: 80,10: 90$, and $0: 100$. The mobile phase was continued with ethyl acetate:methanol 100:0, 90:10, 80:20, 70:30, 60:40, 50:50, 40:60, 30:70, 20:80, 10:90, and 0:100. TLC indexing was performed and observed under UV $254 \mathrm{~nm}$.

\section{Detection Method}

The purity of yield compounds from the isolation was tested by single eluation TLC with three different eluent compositions and two-dimensional TLC. The chemical structure of the isolate was determined using 1D, 2D NMR (HSQC and HMBC), and liquid chromatography-mass spectroscopy (LC-MS). The obtained isolate was observed based on its ability to inhibit activities of $\alpha$-glucosidase and DPP-4. The determination of the content of the isolated compound was tested using LC-MS.

\section{Alpha-glucosidase Inhibitory Assay}

The $\alpha$-glucosidase inhibitory activity was determined according to the method described previously with

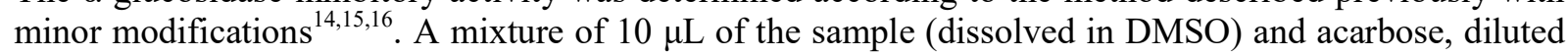
with phosphate buffer at various concentrations. $40 \mu \mathrm{L}$ phosphate buffer $(100 \mathrm{mM}, \mathrm{pH} 6.8)$ and $25 \mu \mathrm{L}$ of a p-nitrophenyl- $\alpha$-D-glucopyranoside substrate (p-NPG; $3.2 \mathrm{mM}$ ), was preincubated at $37^{\circ} \mathrm{C}$ for $10 \mathrm{~min}$. The reaction was initiated by the addition of $25 \mu \mathrm{L}$ of $0.08 \mathrm{unit} / \mathrm{mL} \alpha$-glucosidase enzyme (dissolved in phosphate buffer containing $0.2 \%$ bovine serum albumin) and incubated for additional 15 min at $37^{\circ} \mathrm{C}$. The reaction stopped with the addition of $100 \mu \mathrm{L} \mathrm{Na} \mathrm{CO}_{3}(200 \mathrm{mM})$, producing p-nitrophenol. The inhibitory activity was estimated by measuring the absorbance of p-nitrophenol using an ELISA microplate reader at a wavelength of $405 \mathrm{~nm}$. Individual blanks were prepared to correct background absorbance. Negative control was carried out in the same manner as a sample, but the sample was replaced by a phosphate buffer. Acarbose tablets were dissolved in phosphate buffer and $2 \mathrm{~N} \mathrm{HCl}(1: 1)$ with a concentration of $1.00 \%(\mathrm{w} / \mathrm{v})$. The precipitate was collected by centrifugation, and the supernatant up to $10 \mu \mathrm{L}$ was added to the reaction mixture, similar to the sample. Percentage $\alpha$-glucosidase inhibitory activity was calculated by using the following equation:

Inhibition activity $=(\mathrm{NK}-\mathrm{B})-(\mathrm{S} 1-\mathrm{S} 0) /(\mathrm{NK}-\mathrm{B}) \times 100$

Where, $\mathrm{NK}=$ negative control with enzyme addition; $\mathrm{B}=$ blank without enzyme addition; $\mathrm{S} 1=$ sample with the addition of enzyme; $\mathrm{S} 0=$ blank sample without addition of enzyme.

\section{DPP-4 Inhibitory Assay}

The inhibition of DPP-4 activity was performed using commercial assay kits according to the manufacturer's instructions with modification ${ }^{17,18}$. Sitagliptin was used as the standard inhibitor. DPP-4 was gathered from the blood serum of rats (Wistar). Briefly, $40 \mu \mathrm{L}$ of DPP-4 assay buffer, $10 \mu \mathrm{L}$ of DPP4 enzyme (blood serum), and $10 \mu \mathrm{L}$ of sample solution (in various concentrations) as the inhibitor, were added into the well. After pre-incubating for $10 \mathrm{~min}$ at $37^{\circ} \mathrm{C}, 40 \mu \mathrm{L} \mathrm{H}$-Gly-Pro-AMC as the fluorogenic substrate was added and incubated for $30 \mathrm{~min}$ at $37^{\circ} \mathrm{C}$. In the initial activity wells, the inhibitor was replaced by DPP-4 assay buffer. The fluorescence of free 7-amino-4-methyl coumarin (AMC) was measured using a microplate reader (excitation at $360 \mathrm{~nm}$ and emission at $460 \mathrm{~nm}$ ). The parameter observed was the amount of fluorescence product released upon each sample test. Then, the percentage of inhibition was calculated. Percent DPP-4 inhibition was calculated using the formula:

Inhibition activity $=(\mathrm{IA}-\mathrm{B})-(\mathrm{I}-\mathrm{IB}) /(\mathrm{IA}-\mathrm{B}) \times 100$

Where, $\mathrm{IA}=$ initial activity without inhibitor addition; $\mathrm{B}=$ background without enzyme and inhibitor addition; I = sample as inhibitor (isolate/standard); IB = background sample as inhibitor without enzyme DPP-4 addition. 
RASĀYAN J. Chem.

Vol. 13 | No. 2 |826 - 835| April - June | 2020

\section{Statistical Analyses}

Data were expressed as mean \pm SEM $(n=3)$, and the $\mathrm{IC}_{50}$ values were determined by nonlinear regression curve and fit using GraphPad Prism 8.0.2 software.

\section{RESULTS AND DISCUSSION \\ Result of Isolation and Characterization Isolated Compound}

Fractionation and isolation of EAF using silica gel column chromatography resulted in eight fractions (EAF1-EAF8). EAF2 was the fraction with the best spot data based on TLC. Further separation and purification of EAF2 were carried out with the same method. Analysis of the fractions was performed using TLC. Subfractions showing similar Rf values were combined. The results of isolation of EAF obtained from $96 \%$ EE of tamoenju leaves showed the presence of flavonol compounds. The spots obtained on the TLC plate with isolated compound and standard flavonoid kaempferol is shown in Fig.-2. n-hexane: ethyl acetate $(4: 6 \mathrm{v} / \mathrm{v})$ was used as the mobile phase.

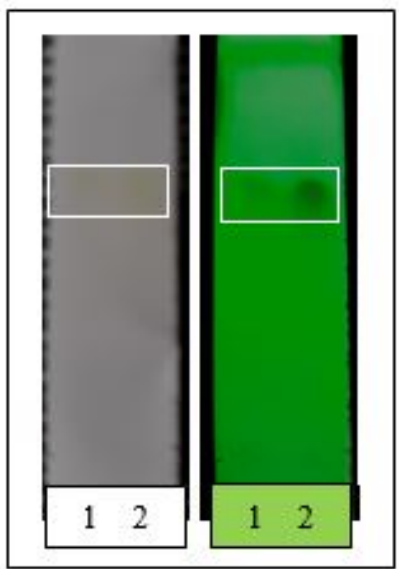

Fig.-2: TLC of Standard Kaempferol (1) and Isolated Compound (2), (a) Visible light, (b) UV $254 \mathrm{~nm}$

The isolated compound was obtained as a yellow amorphous powder. The purity test of the isolated compound was carried out by one dimensional TLC evaluation using various eluents: chloroform:methanol (24:1), chloroform:ethyl acetate (5:2), and n-hexane:ethyl acetate (3:7) and showed a single spot with Rf $0.16,0.47$, and 0.81 respectively. Two dimensional TLC using two mobile phase composition: (1) chloroform:methanol (24:1), and (2) ethyl acetate:n-hexane (7:3). This test obtains a single spot indicating that the isolate was pure (Fig.-3).

The electrospray ionization (ESI)-positive mode mass spectrum by LC-ESI-Q trap (QT)/MS showed a molecular ion peak at $\mathrm{m} / \mathrm{z} 287.0599$ for $[\mathrm{M}+\mathrm{H}]^{+}$corresponding to the molecular formula of $\mathrm{C}_{15} \mathrm{H}_{10} \mathrm{O}_{6}$ (Fig.-4). The ${ }^{1} \mathrm{H}$ NMR spectrum (Fig.-5) of this compound shows the proton signal of a typical flavanol type compound with the $\mathrm{ABX}$ system $(6-8 \mathrm{ppm})$. For the A-ring protons, the presence of a singlet signal at $\delta_{\mathrm{H}} 12.17 \mathrm{ppm}$ means there is an -OH group in C-5. Next, a pair of aromatic proton signals at $\delta_{\mathrm{H}} 6.26$ and $6.53 \mathrm{ppm}(\mathrm{J}=2 \mathrm{~Hz})$ are the signal protons from $\mathrm{C}-6$ and $\mathrm{C}-8$, thus in $\mathrm{C}-7$, there is a $-\mathrm{OH}$ group. Two proton signals aromatic $2 \mathrm{H}$ at $\delta_{\mathrm{H}} 7.02\left(\mathrm{H}-3^{\prime}\right.$ and $\left.\mathrm{H}-5^{\prime}\right)$ and $8.14 \mathrm{ppm}\left(\mathrm{H}-2^{\prime}\right.$ ' and $\mathrm{H}-6$ ') orthopedic coupling $\left(\mathrm{J}=8.9 \mathrm{~Hz}\right.$ ) shows in-ring B has an -OH group on C-4. The ${ }^{13} \mathrm{C}-\mathrm{NMR}$ spectra (Fig.-6) at 94.5 (C-8); 99.2 (C-6); 104.2 (C-10); 116.3 (C-3' and C-5'); 123.3 (C-1'); 130.5 (C-2' and C-6'); 136.6 (C-3); 147.0 (C2); 162.3 (C-5); 160.2 (C-4'); 157.8 (C-9); 164.9 (C-7) and 176.6 (C-4). The ${ }^{1} \mathrm{H}$ and ${ }^{13} \mathrm{C}$ NMR values for all the carbons were assigned based on HSQC and HMBC correlations (Fig.-7 and Table-1). Based on the spectroscopic data, molecular weight data, and reference comparison ${ }^{19,20}$, the isolated compound was identified as kaempferol. The structure of the isolated compound is shown in Fig.-8. This is the first report of the compound in tamoenju plant. The determination of isolated compound levels was performed by LC-MS because it detects more specific compounds based on molecular weight, and the analysis time is short ${ }^{21}$. The level of isolates in this study was $182.23 \mathrm{mg} / \mathrm{g}$ isolate. 
RASĀYAN J. Chem.

Vol. 13 | No. 2 |826 - 835| April - June | 2020

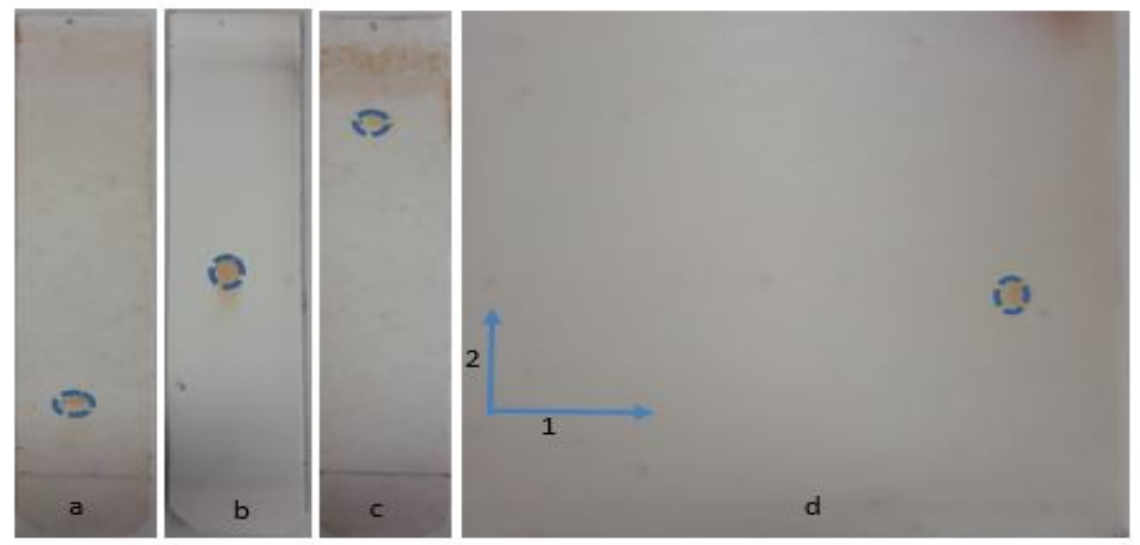

Fig.-3: One and Two Dimensional TLC under Visible Light by Eluents: (a) Chloroform:Methanol (24:1); (b) Chloroform:Ethyl Acetate (5:2); (c) n-Hexane:Ethyl Acetate (3:7); and (d) (1) Chloroform:Methanol (24:1), and (2) Ethyl Acetate:n-Hexane (7:3). The Isolate was pointed with a Blue Circle.
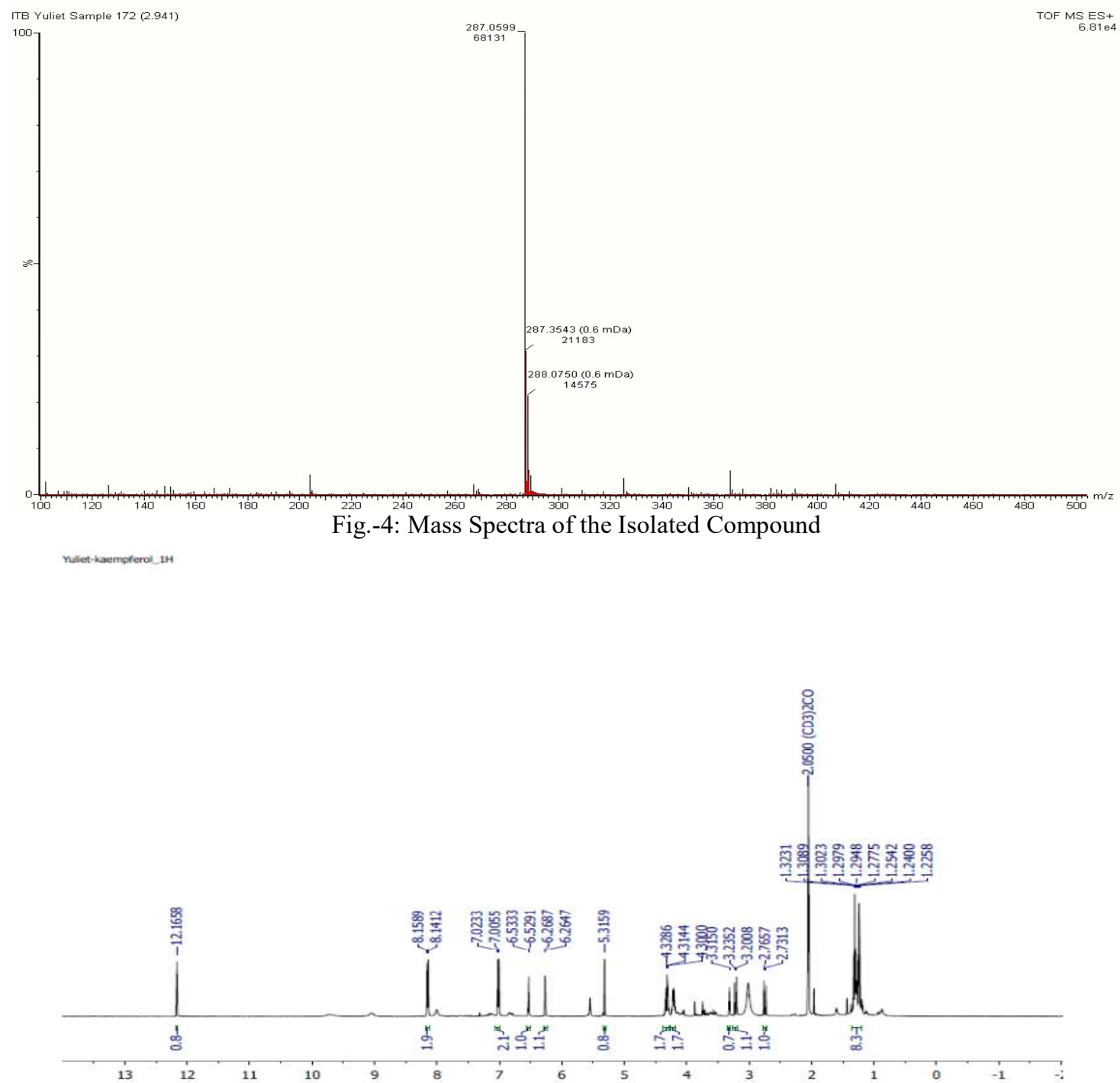

Fig.-5: Spectra ${ }^{1} \mathrm{H}$ NMR of the Isolated Compound 
RASĀYAN J. Chem.

Vol. 13 | No. 2 |826 - 835| April - June | 2020

Yuliet-kaempferol_13C
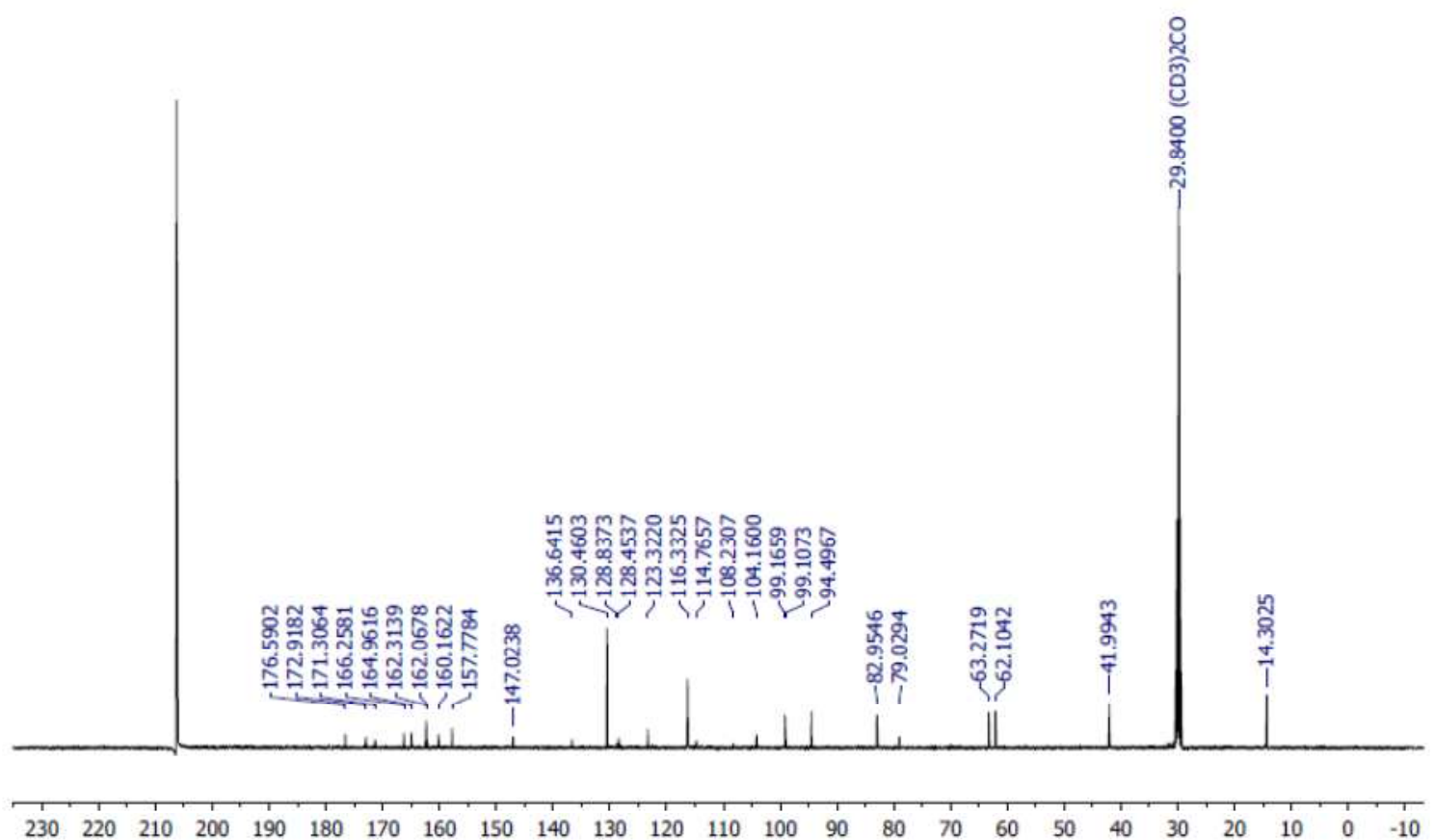

Fig.-6: Spectra ${ }^{13} \mathrm{C}$ NMR of the Isolated Compound

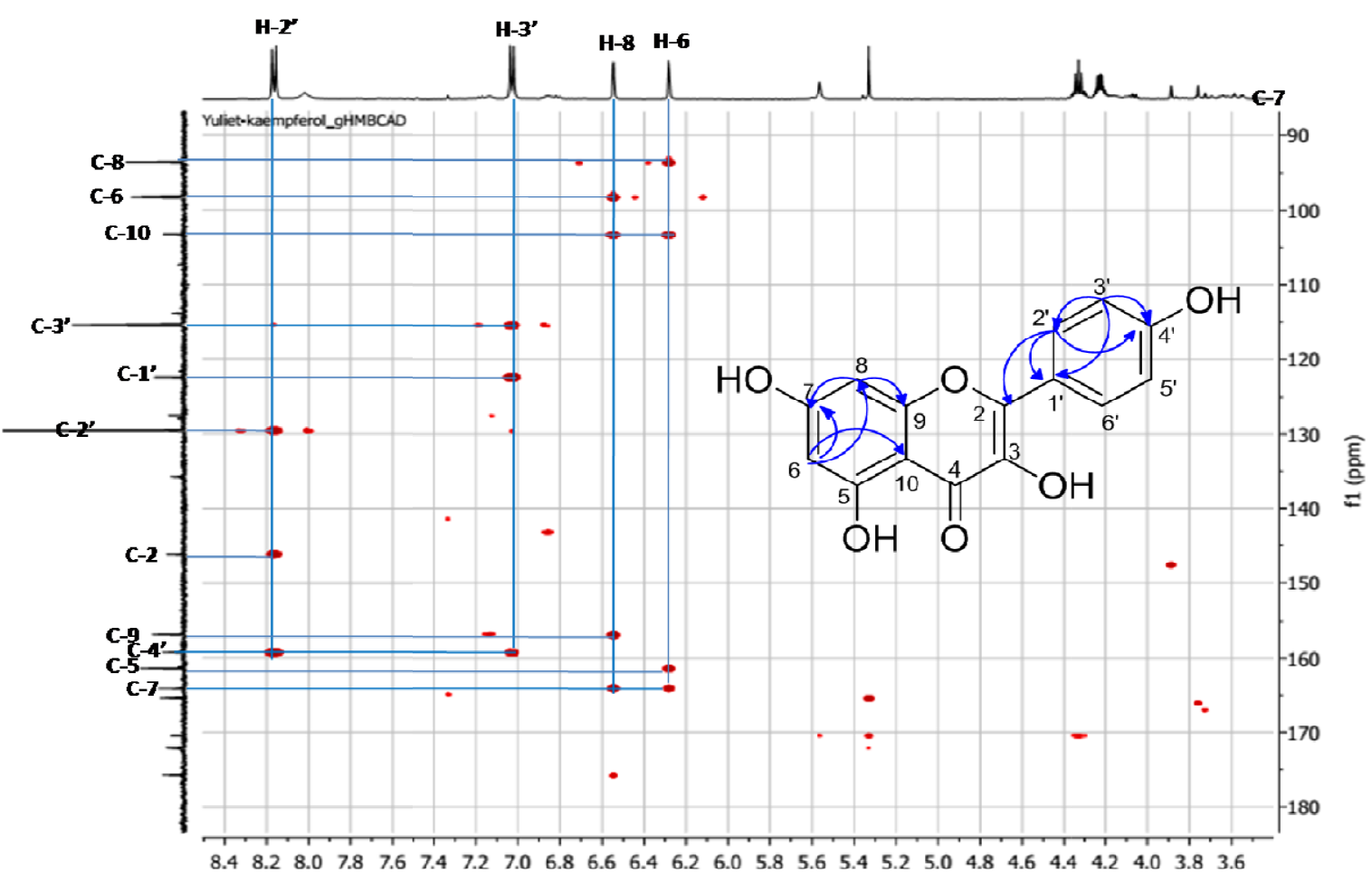

Fig.-7: HMBC NMR Spectrum of the Isolated Compound 
RASĀYAN J. Chem.

Vol. 13 | No. 2 |826 - 835| April - June | 2020

Table-1: ${ }^{1} \mathrm{H}(500 \mathrm{MHz}),{ }^{13} \mathrm{C}(125 \mathrm{MHz})$, and $\mathrm{HMBC}$ of the Isolated Compound $\left[\mathrm{d}_{6}\right.$ acetone $\left.\left(\mathrm{CD}_{3}\right)_{2} \mathrm{CO}\right]$

\begin{tabular}{c|c|c|c}
\hline \multirow{2}{*}{ Position } & \multicolumn{2}{|c|}{ HSQC } & \multirow{2}{*}{ HMBC } \\
\cline { 2 - 4 } & $\mathrm{C}\left(\boldsymbol{\delta}_{\mathrm{C}}, \mathrm{ppm}\right)$ & $\mathrm{H}\left(\boldsymbol{\delta}_{\mathrm{H}}, \mathrm{ppm}, J \mathrm{~Hz}\right)$ & - \\
\hline 1 & - & - & - \\
\hline 2 & 147.0 & - & - \\
\hline 3 & 136.6 & - & - \\
\hline 4 & 176.6 & $12.17(1 \mathrm{H} ; \mathrm{S})$ & - \\
\hline 5 & 162.3 & $6.26(1 \mathrm{H} ; \mathrm{D} ; 2.0 \mathrm{~Hz})$ & $94.5 ; 104.2 ; 162.3 ; 164.9$ \\
\hline 6 & 99.2 & - & - \\
\hline 7 & 164.9 & $6.53(1 \mathrm{H} ; \mathrm{D} ; 2.1 \mathrm{~Hz})$ & - \\
\hline 8 & 94.5 & - & - \\
\hline 9 & 157.8 & - & $147.2 ; 104.2 ; 157.8 ; 164.9$ \\
\hline 10 & 104.2 & $8.14(1 \mathrm{H} ; \mathrm{D} ; 8.85 \mathrm{~Hz})$ & 160.2 \\
\hline $1^{\prime}$ & 123.3 & $7.02(1 \mathrm{H} ; \mathrm{D} ; 8.9 \mathrm{~Hz})$ & - \\
\hline $3^{\prime}$ & 130.5 & - & $147.0 ; 160.2$ \\
\hline $4^{\prime}$ & 116.3 & $8.14(1 \mathrm{H} ; \mathrm{D} ; 8.85 \mathrm{~Hz})$ & $116.3 ; 123.3 ; 160.2$ \\
\hline $5^{\prime}$ & 160.2 & $7.02(1 \mathrm{H} ; \mathrm{D} ; 8.9 \mathrm{~Hz})$ & $123.3 ; 160.2$ \\
\hline 6 & 116.3 & & \\
\hline
\end{tabular}<smiles>O=c1c(O)c(-c2ccc(O)cc2)oc2cc(O)cc(O)c12</smiles>

Fig.-8: Structure of the Isolated Compound (Kaempferol)

\section{Assay for The Antidiabetic Activity of Isolated Compound}

The goal of the treatment of DM is to achieve normal blood glucose levels. One therapeutic approach to reduce postprandial hyperglycemia is to slow glucose absorption by inhibiting carbohydrate hydrolyzing enzymes in the intestine, such as glucosidase ${ }^{22} . \alpha$-Glucosidase is an enzyme that catalyzes the final step of the digestion of carbohydrates; hence $\alpha$-glucosidase inhibitors are compounds that can prevent the metabolism of complex carbohydrates into glucose to slow the use of carbohydrates to suppress postprandial hyperglycemia ${ }^{23,24}$.

DPP enzymes play a role in the conversion of glucagon-like-peptide-1 (GLP-1) to its metabolites. GLP-1 is a peptide hormone that plays a role in the stimulation of insulin release; thus, inhibition of DPP-4 can regulate blood sugar levels in people with diabetes. The inhibition of GLP-1 degradation by DPP-4 inhibitors (incretin enhancers) causes endogenous GLP-1 to remain at normal levels. Therefore, DPP-4 inhibitors have the potential to be antidiabetic agents. Furthermore, DPP-4 inhibitors repair organ systems which deteriorate in diabetes type 2 , making this class of drug a target for development in the treatment of diabetes $^{25,26}$.

There is an increasing number of studies to develop effective new $\alpha$-glucosidase and DPP-4 inhibitors with minimal side effects, obtained from medicinal plants. This study investigated the antidiabetic activity of the isolated compound by determining the inhibitory activity against $\alpha$-glucosidase and DPP-4 enzymes in vitro. The effects of the isolate and acarbose concentrations on $\alpha$-glucosidase activity are shown in Table-2. The isolate inhibited $\alpha$-glucosidase with an $\mathrm{IC}_{50}$ value of $27.78 \pm 0.86 \mu \mathrm{g} / \mathrm{mL}$ compared to acarbose, as a standard drug, with an $\mathrm{IC}_{50}$ of $17.80 \pm 0.27 \mu \mathrm{g} / \mathrm{mL}$ (approximately 1:1.5) (Table-2). The results showed that the isolated compound has an excellent capability to inhibit $\alpha$-glucosidase. Although 
RASĀYAN J. Chem.

Vol. 13 | No. 2 |826 - 835| April - June | 2020

$\mathrm{IC}_{50}$ values are significantly different, natural bioactive compounds may be safe for use as alternative medicines to manage diabetes mellitus. Several studies also showed kaempferol as an $\alpha$-glucosidase inhibitor with different $\mathrm{IC}_{50}$ values ${ }^{12,27,28}$. The results of this study demonstrated that kaempferol possesses potent $\alpha$-glucosidase inhibitory activity.

Table-2: Percentage Inhibitory Activity of the Isolated Compound on $\alpha$-Glucosidase Activity in Comparison with Acarbose $(n=3)$

\begin{tabular}{|c|c|c|c|}
\hline Sample & Concentration $(\mu \mathrm{g} / \mathrm{mL})$ & Inhibition percentage (\%) & $\mathrm{IC}_{50}(\mu \mathrm{g} / \mathrm{mL})$ \\
\hline \multirow[t]{7}{*}{ Isolate } & 5 & $29.12 \pm 0.33$ & \multirow{7}{*}{$27.78 \pm 0.86$} \\
\hline & 10 & $30.97 \pm 0.47$ & \\
\hline & 20 & $34.45 \pm 0.81$ & \\
\hline & 40 & $49.29 \pm 0.17$ & \\
\hline & 60 & $50.29 \pm 0.14$ & \\
\hline & 80 & $51.89 \pm 0.37$ & \\
\hline & 100 & $53.56 \pm 0.01$ & \\
\hline \multirow[t]{6}{*}{ Acarbose } & 2.5 & $21.73 \pm 0.55$ & \multirow{6}{*}{$17.80 \pm 0.27$} \\
\hline & 5.0 & $28.41 \pm 0.15$ & \\
\hline & 10 & $35.63 \pm 0.33$ & \\
\hline & 20 & $44.38 \pm 1.07$ & \\
\hline & 40 & $57.43 \pm 0.19$ & \\
\hline & 80 & $97.74 \pm 0.28$ & \\
\hline
\end{tabular}

The isolated compounds from EAF were used to determine DPP-4 inhibitory activity compared to sitagliptin (positive control). The results are shown in Table-3. The highest inhibitory activity was that of the isolated compound with an $\mathrm{IC}_{50}$ of $7.37 \pm 0.06 \mu \mathrm{g} / \mathrm{mL}$, whereas sitagliptin exhibited an $\mathrm{IC}_{50}$ of 25.56 $\pm 0.43 \mu \mathrm{g} / \mathrm{mL}$. These results demonstrated that kaempferol obtained from the EAF of tamoenju leaves were effective in inhibiting DPP-4. Similar results were obtained by Zhao et al. ${ }^{29}$, Sarian et al. ${ }^{12}$, and Gao et $a l^{30}$, although the $\mathrm{IC}_{50}$ results obtained were slightly different due to different experimental conditions. This supports our conclusion that kaempferol is an active compound from the EAF of tamoenju leaves that have a significant DPP-4 inhibitory potential and is a potential herbal-based DPP-4 inhibitor.

Table-3: Percentage Inhibitory Activity of the Isolated Compound on DPP-4 in Comparison with Sitagliptin ( $\mathrm{n}=3$ )

\begin{tabular}{|c|c|c|c|}
\hline Sample & Concentration $(\mu \mathrm{g} / \mathrm{mL})$ & Inhibition percentage $(\%)$ & $\mathrm{IC}_{50}(\mu \mathrm{g} / \mathrm{mL})$ \\
\hline \multirow[t]{7}{*}{ Isolate } & 1.25 & $25.51 \pm 0.32$ & \multirow{7}{*}{$7.37 \pm 0.06$} \\
\hline & 2.5 & $31.85 \pm 0.42$ & \\
\hline & 5 & $33.41 \pm 0.45$ & \\
\hline & 10 & $82.00 \pm 0.13$ & \\
\hline & 20 & $82.73 \pm 0.02$ & \\
\hline & 40 & $86.74 \pm 0.21$ & \\
\hline & 80 & $94.63 \pm 0.20$ & \\
\hline \multirow[t]{6}{*}{ Sitagliptin } & 1.25 & $22.31 \pm 1.35$ & \multirow{6}{*}{$25.56 \pm 0.43$} \\
\hline & 2.5 & $26.53 \pm 0.84$ & \\
\hline & 5 & $31.93 \pm 0.01$ & \\
\hline & 20 & $42.59 \pm 1.97$ & \\
\hline & 40 & $57.79 \pm 1.77$ & \\
\hline & 200 & $77.73 \pm 0.59$ & \\
\hline
\end{tabular}

\section{CONCLUSION}

Isolation and identification of chemical compounds from the EAF demonstrated that one of the flavonoid compounds in the leaves of tamoenju was kaempferol. Although this compound was previously reported as an $\alpha$-glucosidase and DPP-4 inhibitor from other plants, its presence in tamoenju (Hibiscus surattensis L.) leaves is reported for the first time, which will further contribute to the chemical profile of the compound. The leaves of this plant are a source for developing $\alpha$-glucosidase and DPP-4 inhibitors. 


\section{ACKNOWLEDGMENT}

The authors would like to thank the Ministry of Research, Technology, and Higher Education of the Republic of Indonesia and Indonesia Endowment Fund for Education (LPDP) for the funding through the BUDI DN Scholarship with the cooperation contract number: PRJ-109/LPDP.4/2019. We also thank Editage (www.editage.com) for English language editing.

\section{REFERENCES}

1. Elfahmi, H.J. Woerdenbag, and O. Kayser, Journal of Herbal Medicine, 4(2), 51(2014), DOI: 10.1016/j.hermed.2014.01.002.

2. Muharni, Elfita, R. Adillah, H. Yohandini, and Julinar, Molekul, 13(1), 38(2018), DOI: 10.20884/1.jm.2018.13.1.402.

3. Moorthy, P. M. Rajan, S. Sathyanarayanan, K. Muniyandi, D. Sivaraj, S.P. Sasidharan, P. Thangaraj, Journal of Culinary Science \& Technology, 1(2018), DOI: 0.1080/15428052.2018.1502110.

4. G. Akarca, Industrial Crops \& Products, 137, 285(2019), DOI:10.1016/j.indcrop.2019.05.043.

5. R. Triani, R. Pitopang, and Yuliet., Biocelebes, 9(1), 28(2015), DOI: 10.22487/j25805991.2015.v9.i1.4388.

6. M. Fajrin, N. Ibrahim, and A. W. Nugrahani, Galenika Journal of Pharmacy, 1(2), 92(2015), DOI: 10.22487/j24428744.2015.v1.i2.6239.

7. D. Deb, B.K. Datta, J. Debbarma, and S. Deb, Biodiversitas, 17(1), 256(2016), DOI: 10.13057/biodiv/d170137.

8. A. Gbolade, Journal of Ethnopharmacology, 144, 1(2012), DOI: 10.1016/j.jep.2012.07.018.

9. Yuliet, E.Y. Sukandar, and I.K. Adnyana, The Natural Products Journal, (2020 in press), DOI: 10.2174/2210315509666190626125330.

10. S. Sultana, S., A.A Faruq, N. A. Rashid, T. Nasim, and M. Q. Ahsan, European Journal of Pharmaceutical and Medical Research, 5(4), 167(2018).

11. Yuliet, E.Y. Sukandar, and I. K. Adnyana, Indonesian Journal of Pharmaceutical Science and Technology, Supp 1(1), 25(2018), DOI:10.15416/ijpst.v1i1.16120.

12. M.N. Sarian, Q. U. Ahmed, S. Z. Mat So'ad, A. M. Alhassan, S. Murugesu, V. Perumal, S. N. A. S. Mohamad, A. Khatib, and J. Latip, BioMed Research International, 2017(8386065), (2017), DOI: $10.1155 / 2017 / 8386065$.

13. M. Insanu, S.Aziz, I. Fidrianny, R. Hartati, Elfahmi, Sukrasno and R. Wirasutisna, Rasayan Journal of Chemistry, 12(2), 519(2019), DOI:10.31788/RJC.2019.1221831.

14. Y.M. Kim, Y.K. Jeong, M.H. Wang, W.Y. Lee, and H.I. Rhee, Nutrition 21(6), 756(2005), DOI: 10.1016/j.nut.2004.10.014.

15. Kissinger, A. Yamani, and R.M.N. Pitri, Research Journal of Medicinal Plants, 10(5), 356(2016), DOI: $10.3923 /$ rjmp.2016.356.361.

16. Okselni, T., Santoni, A., Dharma, A. \& Efdi, M. Rasayan Journal of Chemistry, 12(1), 146(2019), DOI: $10.31788 /$ RJC.2019.1215019.

17. Sigma-Aldrich, DPP-IV Activity Assay Kit (MAK088), Technical Buletin, 2014, https://www.sigmaaldrich.com/catalog/product/sigma/mak088.

18. M. Ekayanti, R. Sauriasari, and B. Elya, Pharmacognosy Journal, 10(1), 190(2018), DOI: 10.5530/pj.2018.1.32.

19. C. Liu, J. Chen, and J.H. Wang, Chemistry of Natural Compounds, 45(6), 808(2009), DOI: 10.1007/s10600-010-9500-1.

20. L.J. Lin, X.B. Huang, and Lv. ZC, SpringerPlus, 5(1), 1649(2016), DOI: 10.1186/s40064-016-33089.

21. B.R. Kumar, Journal of Pharmaceutical Analysis, 7(6), 349(2017), DOI: 10.1016/j.jpha.2017.06.005.

22. D.F. Pereira, L. H. Cazarolli, C. Lavado, V. Mengatto, M. S. R. B. Figueiredo, A. Guedes, M. G. Pizzolatti, and F. R. M. B. Silva, Nutrition, 27, 1161(2011), DOI: 10.1016/j.nut.2011.01.008.

23. D.Q. Li, Z.M. Qian, and S.P. Li, Journal of Agricultural and Food Chemistry, 58(11), 6608(2010), DOI: $10.1021 / \mathrm{jf1} 00853 \mathrm{c}$. 
RASĀYAN J. Chem.

Vol. 13 | No. 2 |826 - 835| April - June | 2020

24. A. Malik, L. Marpaung, M.P. Nasution, and P. Simanjuntak, Rasayan Journal of Chemistry, 12(3), 1175(2019), DOI: $10.31788 /$ RJC.2019.1235082.

25. A.M. Lambeir, C. Durinx, S. Scharpé, and I. D. Meester, Critical Reviews in Clinical Laboratory Sciences, 40(3), 209(2003), DOI:10.1080/713609354.

26. R. Chakrabarti, S. Bhavtaran, P. Narendra, N. Varghese, L. Vanchhawng, M. S. Shihabudeen, and K.Thirumurgan, Journal of Natural Products, 4, 158(2011).

27. C. Proenca, M. Freitas, D. Ribeiro, E. F. T. Oliveira. J. L. C. Sousa S. M. Tome, M. J. Ramos, A. M. S. Silva, P. A. Fernandes and E. Fernandes, Journal of Enzyme Inhibition and Medicinal Chemistry, 32(1), 1216(2017), DOI: 10.1080/14756366.2017.1368503.

28. Z. Sheng, B. Ai, L. Zheng, X. Zheng, Z. Xu, Y. Shen and Z. Jin, International Journal of Food Science and Technology, 53(3), 755(2018), DOI:10.1111/ijfs.13579.

29. B.T. Zhao, D.D. Le, P.H.Nguyen, M.Y Ali, J.S. Choi, B.S. Min, H.M. Shin, H.I. Rhee, and M. H. Woo, Chemico-Biological Interactions, 253, 27(2016), DOI:10.1016/j.cbi.2016.04.012.

30. Y. Gao, Y. Zhang, J. Zhu, B. Li, W. Zhu, J. Shi, Q. Jia, and Y. Li, Future Medicinal Chemistry, 7(8), 1079(2014), DOI: 10.4155/fmc.15.49.

[RJC-5607/2019] 